\title{
Article \\ Thermodynamic Analysis of Waste Vegetable Oil Conversion to Biodiesel with Solar Energy
}

\author{
José A. León (D), Gisela Montero*(D), Marcos A. Coronado (D), José R. Ayala (D), Daniela G. Montes (D), \\ Laura J. Pérez (D), Lisandra Quintana $(D)$ and Jesús M. Armenta
}

check for

updates

Citation: León, J.A.; Montero, G.;

Coronado, M.A.; Ayala, J.R.; Montes, D.G.; Pérez, L.J.; Quintana, L.;

Armenta, J.M. Thermodynamic

Analysis of Waste Vegetable Oil

Conversion to Biodiesel with Solar

Energy. Energies 2022, 15, 1834.

https://doi.org/10.3390/en15051834

Academic Editor: Audrius

Bagdanavicius

Received: 20 January 2022

Accepted: 24 February 2022

Published: 2 March 2022

Publisher's Note: MDPI stays neutral with regard to jurisdictional claims in published maps and institutional affiliations.

Copyright: (C) 2022 by the authors. Licensee MDPI, Basel, Switzerland. This article is an open access article distributed under the terms and conditions of the Creative Commons Attribution (CC BY) license (https:// creativecommons.org/licenses/by/ $4.0 /)$.
Instituto de Ingeniería, Universidad Autónoma de Baja California, Boulevard Benito Juárez y Calle de la Normal S/N, Colonia Insurgentes Este, Mexicali 21280, Mexico; jose.leon30@uabc.edu.mx (J.A.L.);

marcos.coronado@uabc.edu.mx (M.A.C.); ramon.ayala@uabc.edu.mx (J.R.A.); dmontes35@uabc.edu.mx (D.G.M.); lperez7@uabc.edu.mx (L.J.P.); quintana.lisandra@uabc.edu.mx (L.Q.); a1174515@uabc.edu.mx (J.M.A.)

* Correspondence: gmontero@uabc.edu.mx

\begin{abstract}
Exergy and energy analyses of two biodiesel production processes that integrate solar energy as the main energy source were developed to determine the process with the higher efficiency from an energy and exergy approach. The biodiesel production processes were simulated in ASPEN PLUS $^{\circledR}$, and the solar energy supply was studied in TRNSYS ${ }^{\circledR}$, using EXCEL ${ }^{\circledR}$ simultaneously for the exergetic analysis. The solar thermal energy collection system can supply $81 \%$ of the energy required by the alkali process in the Flash separation equipment. For the supercritical process, solar thermal energy can supply $74.5 \%$ of the energy in the preheating and separation stages. The energy efficiency of the supercritical process is higher; nevertheless, the exergetic efficiency of the alkaline process is higher than the supercritical one. Solar collection systems contribute from $85 \%$ to $93 \%$ of the exergy destroyed by the global process for both cases. The alkaline biodiesel production process has the highest advantages when using solar energy as the main source of energy, compared to a process in supercritical conditions that presents greater irreversibilities and requires more infrastructure to collect the solar resource. However, using solar energy as the foremost energy source offers an alternative to fossil fuels, and it provides an environmental benefit concurrently with the use of biodiesel.
\end{abstract}

Keywords: solar energy; energy analysis; exergy analysis; renewable energy; sustainability

\section{Introduction}

Approximately $86.4 \%$ of the energy resources required by man are supplied by fossil fuels, which has increased environmental and health problems worldwide [1]. By 2030, the transport sector will consume the same amount of fossil fuels that all sectors consumed in 2003 worldwide, approximately 55,029 Mtoe [2].

The heating process constitutes more than $35 \%$ of the energy consumed industrially in the world, commonly the temperature of the heat supply of industrial processes is below $400{ }^{\circ} \mathrm{C}$, and approximately $80 \%$ of the energy used to produce it comes from natural gas and petroleum derivatives [3]. Therefore, the consumption of renewable energies such as solar, wind, hydraulic, and biomass energy is very relevant. Solar energy has a great potential to produce clean and environmentally friendly heating.

Industry energy demand has been on the rise in recent decades; even as equipment specifications and process operation have improved, inefficiencies in the conversion and utilization of process energy remain a significant factor for the reduction in energy consumption [4]. Exergy represents the amount of useful work that can be obtained from a system when it is brought into thermodynamic equilibrium with the environment. Exergy analysis of a process allows focusing on the thermodynamic losses and inefficiencies of each unit or block in a production process. However, the number of studies based on the exergy of 
industrial chemical processes is lower than in other research fields [5]. The analysis of mass and energy flows in a system is fundamental for the reduction in energy consumption.

The use of renewable energies contributes to achieving the sustainability of the process. Biofuels are a renewable energy source that has been a viable alternative to face the growing energy demand due to their environmental advantages. However, its integration into the world energy market remains predominantly weak, being less than $13 \%$ worldwide [6]. Biodiesel continues to be the highest production biofuel in the world, and the European Union is the largest producer, where $70 \%$ of biofuel is produced for the transport sector [7]. Developing countries are highly dependent on imported fossil fuels such as diesel and simultaneously face the challenge of reducing their greenhouse gas emissions [8].

Biodiesel is obtained by the transesterification of triglycerides with alcohol in the presence of a catalyst, biocatalyst, or without a catalyst [9]. Conventional methods for biodiesel production are named according to the type of catalyst used and include acid, alkaline, and enzymatic, all in a homogeneous form. The use of catalysts seeks to reduce reaction times and achieve the desired reaction conditions [10]. A widely used variant is the alkaline, which uses batch-type reactors with a reaction time of $1 \mathrm{~h}, 1 \mathrm{~atm}, 65^{\circ} \mathrm{C}$, and a typically molar ratio of alcohol to triglyceride of 6:1 [11]. These conditions are achieved by adding $\mathrm{KOH}, \mathrm{NaOH}$, or $\mathrm{CH}_{3} \mathrm{ONa}$ [12]. However, this type of catalyst hinders the separation process, and if free fatty acid (FFA) content is not taken care of, the resulting reaction produces soap instead of biodiesel [13]. Currently, heterogeneous catalysts have been studied for biodiesel production, mainly composed of oxides, metals, zeolites, or animal waste with high calcium content $[14,15]$. Once the biodiesel is obtained, these catalysts simplify the separation process at a lower cost than conventional chemicals. One of its main disadvantages is the reaction times, which are longer than those using homogeneous catalysts [15].

The supercritical process allows using low-quality feedstocks for biodiesel production, e.g., oils with higher levels of FFA or moisture. The triglycerides are converted to biodiesel directly by applying this process. Neither FFA nor water harms the process. Several studies of the noncatalytic transesterification process with methanol and ethanol were carried out at temperatures ranging from 280 to $425^{\circ} \mathrm{C}$, pressures ranging from 8 to $43 \mathrm{MPa}$, a molar ratio of alcohol to oil ranging from 6:1 to 50:1, and reaction times ranging from 4 to $90 \mathrm{~min}$ depending on the type of oil and equipment used. These variables influence the process's effectiveness and biodiesel yield [16]. Studies were conducted on the integration of solar energy in the biodiesel production process. Most studies focused on a laboratory scale, integrating solar energy in the reaction stage, directly concentrating the solar radiation with a Scheffler reflector or Fresnel lenses [17-19]. Solar energy integration in different areas of the biodiesel production process was marginally studied. If a greater scaling is considered, it is necessary to use linear parabolic trough collectors (PTC) to supply a large energy demand [20]. PTC are the most appropriate technologies to supply solar thermal energy at medium temperature ranges due to their ability to maintain significant stability in the energy supply to a process [21].

A significant amount of exergetic studies are focused on the analysis of combustion engines where biodiesel is used as fuel to study the behavior of the engines at different mixtures of diesel-biodiesel, which allows the identification of diverse operating parameters [22-24]. In general, studies show that energy and exergetic efficiency is higher when using biodiesel as fuel in these engines [25]. Exergy analysis of a transesterification process provides relevant information to reduce irreversibilities and optimize the process in terms of mass and energy.

Few exergetic studies analyze the integration of renewable energies in biodiesel production; most of them were performed comparing different production methods to identify the system irreversibilities and exergetic efficiencies, thus seeking to reduce the exergy destruction [26]. Some studies show that the use of different catalysts has an effect on reducing exergy destruction [27]. Reaction conditions effects on exergy were also carried out [28]. Extensive exergy analysis was developed to study biodiesel production with dif- 
ferent raw materials, such as waste vegetal oil (WVO) and rapeseed crops. The results show that the biodiesel produced from WVO consumes fewer resources than the production from rapeseed crops [29]. Recent exergy analyses of a biodiesel production process with solar energy integration were performed for alkaline production and the cogeneration of electrical energy through an organic Rankine cycle [30]. It highlights the potential of solar energy as an energy source for biodiesel production and the relevance of exergetic analysis in the development and implementation of new technologies.

With the development of different clean technologies and the growing need to obtain energy in a sustainable and economically viable way, research efforts were made to integrate unlike renewable energy sources to satisfy the energy needs of different processes [31,32]. Nevertheless, there are no reported works that extensively analyze the energy and exergetic behavior of biodiesel processes that integrate solar energy. Despite presenting significant advantages in biofuel purification, the exergetic analysis of supercritical processes has been less studied and contrasted with conventional ones. Therefore, the present work analyzed and compared two processes for biodiesel production that integrate solar energy to determine the process with the higher efficiency from an energy and exergy approach. The study included the structure, simulation, and comparison between biodiesel produced through alkaline catalysis and biodiesel obtained under supercritical conditions. The energy and exergetic efficiencies were evaluated for each process and stage, identifying the utmost inefficiencies and highlighting the advantages and disadvantages for each process.

\section{Materials and Methods}

The biodiesel production process was simulated in ASPEN PLUS ${ }^{\circledR}$, and the solar energy supply was studied for the annual average environmental conditions of Mexicali, Baja California, México in TRNSYS ${ }^{\circledR}$, following the methodology developed in previous works $[33,34]$. The supply and storage system of the thermal energy necessary to operate the process was implemented by the solar heating of a heat transfer fluid (HTF). EXCEL ${ }^{\circledR}$ was used simultaneously for the exergetic analysis.

\subsection{Raw Material}

Various simulations used triolein as a representative component of canola oil and methyl oleate as biodiesel [35]. In this study, canola WVO was represented by triolein, FFA as $7 \%$ oleic acid, and biodiesel by methyl oleate.

\subsection{Reaction Methods}

When using WVO as a raw material to produce biodiesel by an alkaline catalyzed reaction, it is necessary to include pretreatment of the raw material, which consists of an esterification reaction of the FFA contained in the WVO and thus avoid the subsequent formation of soaps and emulsions [36]. After pretreatment, the transesterification reaction of the triglycerides contained in the WVO takes place. In Equations (1) and (2), the esterification and transesterification reactions are observed, respectively.

$$
\begin{gathered}
\mathrm{RCOOH}+\mathrm{CH}_{3} \mathrm{OH} \leftrightarrow \mathrm{RCOOCH}_{3}+\mathrm{H}_{2} \mathrm{O} \\
\mathrm{C}_{3} \mathrm{H}_{5}(\mathrm{OCOR})_{3}+3 \mathrm{CH}_{3} \mathrm{OH} \leftrightarrow 3 \mathrm{RCOOCH}_{3}+\mathrm{C}_{3} \mathrm{H}_{5}(\mathrm{OH})_{3}
\end{gathered}
$$

Generally, both reactions are performed at $1 \mathrm{~atm}$ and $328.15 \mathrm{~K}$ to $333.15 \mathrm{~K}$, close to the boiling point of low molecular weight alcohols that are commonly used.

The most common supercritical process consists of the transesterification of triglycerides and the simultaneous esterification of FFA from $8400 \mathrm{kPa}$ to $35,000 \mathrm{kPa}$ and $320^{\circ} \mathrm{C}$ to $350{ }^{\circ} \mathrm{C}$ [37]. The reaction conditions allow that, simultaneously with the transesterification of the triglycerides, the formed glycerol decomposes into 1,2,3 trimethyl glycerol triether, which is a valuable fuel additive [38]. Equation (3) shows the global transesterification reaction for triglycerides under supercritical conditions. For the conversion of FFAs presented in WVO, Equations (1) and (3) were simultaneously used.

$$
\mathrm{C}_{3} \mathrm{H}_{5}(\mathrm{OCOR})_{3}+6 \mathrm{CH}_{3} \mathrm{OH} \leftrightarrow 3 \mathrm{RCOOCH}_{3}+\mathrm{C}_{3} \mathrm{H}_{5}\left(\mathrm{OCH}_{3}\right)_{3}+3 \mathrm{H}_{2} \mathrm{O}
$$




\subsection{Biodiesel Production Processes}

The biodiesel production processes were divided into three main stages: reaction, biodiesel purification, and methanol recovery. The reaction stage was considered from the reactant feed streams to the reactor outlet. Purification of biodiesel comprises the equipment needed to separate the biodiesel by-products created in the reaction step. Finally, the methanol recovery stage takes the secondary streams of biodiesel purification until obtaining a stream with a composition nearby $95 \%$ by weight of methanol required to enter the process again. For both cases, $100 \mathrm{~kg} / \mathrm{h}$ of $\mathrm{WVO}$ were processed. Figure 1 displays the two biodiesel production routes.

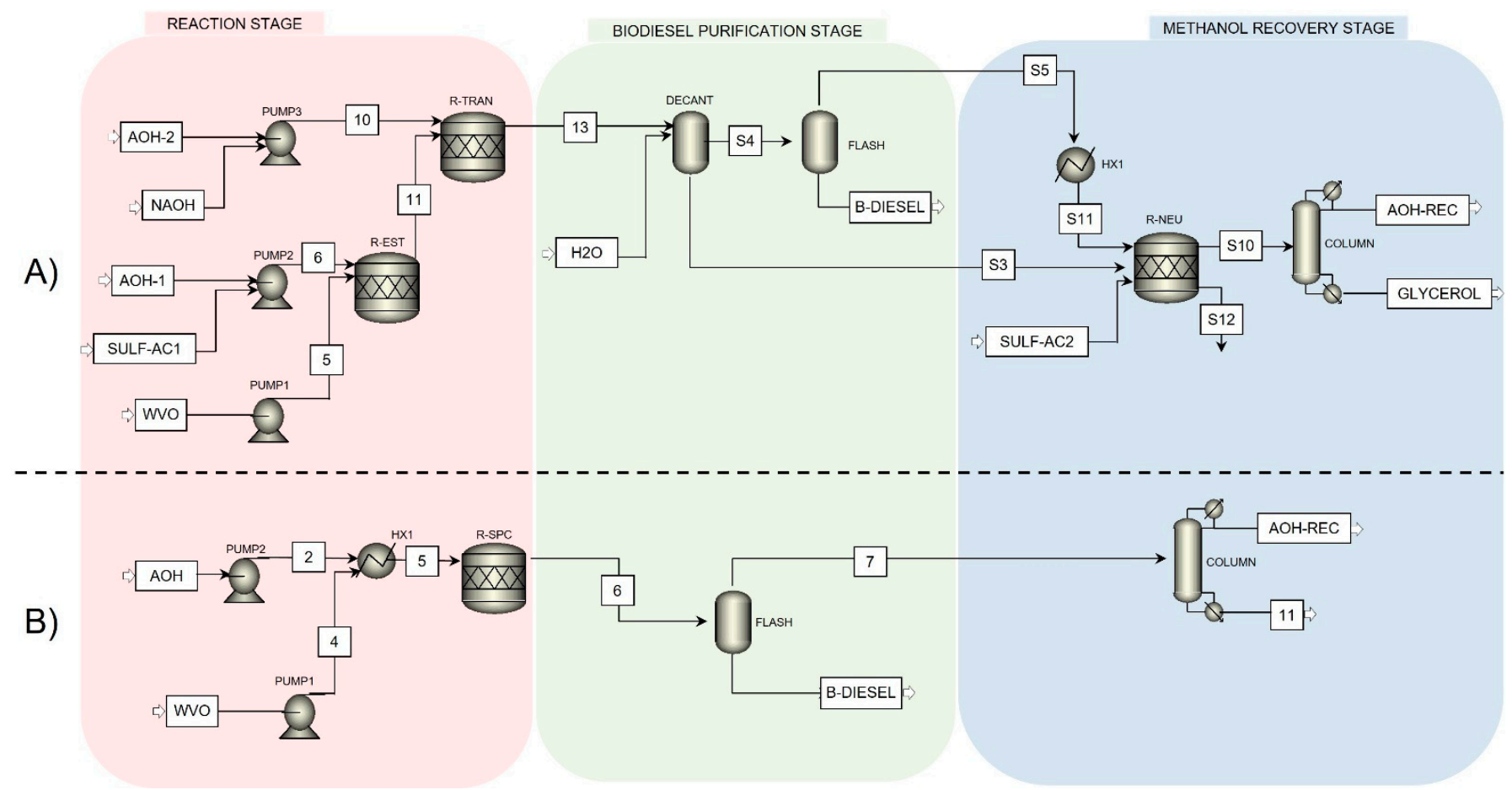

Figure 1. ASPEN PLUS ${ }^{\circledR}$ diagram of biodiesel production process by alkaline catalysis (A) and supercritical conditions (B).

In the alkaline process, described by Figure $1 \mathrm{~A}$, the stream AOH-1 and SULF-AC1 contain methanol and sulfuric acid, respectively, which reacted in R-EST together with the WVO stream. The reaction took place in a stoichiometric reactor with a yield of $95 \%$ at $200 \mathrm{kPa}$ and $50^{\circ} \mathrm{C}$. The products of the acid pretreatment were combined in the R-TRANS reactor with methanol and sodium hydroxide as a catalyst from the AOH-2 and NAOH streams, respectively. The transesterification of the WVO takes place in the R-TRANS reactor. The reaction was performed in a stoichiometric reactor with a yield of $95 \%$ at $200 \mathrm{kPa}$ and $65{ }^{\circ} \mathrm{C}$. After the reaction, the biodiesel purification was accomplished in DECANT and FLASH separator. The decantation occurred at atmospheric temperature and pressure. The $\mathrm{H} 2 \mathrm{O}$ stream was added to the decanter with $200 \mathrm{~kg} / \mathrm{h}$ of water. The FLASH device is a flash separation tank, where the last purification step of biodiesel was performed. Flash separation was performed at $101 \mathrm{kPa}$ and $120^{\circ} \mathrm{C}$. Biodiesel was obtained into stream B-DIESEL, while in stream S5, a mixture of water and methanol was recovered. Both streams S5 and S3 were taken to the methanol recovery stage. In this stage, the neutralization with acid and the recovery of methanol were performed. The streams S5 and S3 were fed to the R-NUE reactor with $0.58 \mathrm{~kg} / \mathrm{h}$ of sulfuric acid in SULF-AC2. The distillation in COLUMN was reached in nine stages, S10 stream was fed in stage four with a reflux ratio of 1 . In the AOH-REC stream, the excess methanol was recovered, while in the GLYCEROL stream, a mixture of mainly glycerin and water was obtained. 
In Figure 1B supercritical conditions process diagram, oil and methanol were fed to the R-SPC reactor at $10,000 \mathrm{kPa}$ and $350^{\circ} \mathrm{C}$. In the R-SPC, the biodiesel was obtained through the transesterification (Equation (3)) and esterification (Equation (1)) reactions of the chemical species. Both reactions with a yield of $95 \%$. A molar ratio of methanoltriglycerides and methanol-AGL of 9:1 was applied. Biodiesel purification was carried out in a FLASH separator, under $101 \mathrm{kPa}$ and $95{ }^{\circ} \mathrm{C}$. Finally, stream 7 was sent to a distillation column, where the main objective was the recovery of unreacted methanol excess. The distillation was developed in 10 stages, with feed in stage four and a reflux ratio of 1.5. Table 1 describes the operating conditions of the necessary equipment for biodiesel production in both simulations.

Table 1. Operating conditions and considerations for simulations blocks.

\begin{tabular}{|c|c|c|c|c|c|}
\hline EQUIPMENT & NAME & $\begin{array}{l}\text { TEMPERATURE } \\
\left({ }^{\circ} \mathrm{C}\right)\end{array}$ & $\begin{array}{l}\text { PRESSURE } \\
\text { (bar) }\end{array}$ & $\begin{array}{l}\text { PROPERTY } \\
\text { METHOD }\end{array}$ & $\begin{array}{l}\text { BLOCK MODEL } \\
\text { CONSIDERATIONS }\end{array}$ \\
\hline \multicolumn{6}{|l|}{ ALKALINE PROCESS } \\
\hline WVO Pump & PUMP1 & 25 & 2 & NRTL & Isentropic efficiency 0.9 \\
\hline Methanol- $\mathrm{H}_{2} \mathrm{SO}_{4}$ Pump & PUMP2 & 25 & 2 & NRTL & Isentropic efficiency 0.9 \\
\hline Methanol-NaOH Pump & PUMP3 & 25 & 2 & NRTL & Isentropic efficiency 0.9 \\
\hline Esterification Reactor & R-EST & 50 & 2 & NRTL & Stoichiometric reactor, 0.95 conversion \\
\hline Transesterification Reactor & R-TRAN & 65 & 2 & NRTL & Stoichiometric reactor, 0.95 conversion \\
\hline Neutralization Reactor & R-NEU & 50 & 1 & NRTL & Stoichiometric reactor, 0.98 conversion \\
\hline Decanter & DECANT & 30 & 2 & NRTL & Key component mole fraction 0.8 \\
\hline Flash Separator & FLASH & 120 & 1 & NRTL & Two outlet flash drum \\
\hline Condenser & HX1 & 92.7 & 1 & NRTL & Outlet vapor fraction 0.0 \\
\hline \multirow[t]{2}{*}{ Distillation Column } & COLUMN (Top) & 58.7 & 0.8 & NRTL & 9 stages, feed at stage 4 , reflux \\
\hline & COLUMN (Bottom) & 105.41 & 1 & NRTL & ratio 0.3 , distillate to feed ratio 0.8 \\
\hline \multicolumn{6}{|c|}{ SUPERCRITICAL PROCESS } \\
\hline WVO Pump & PUMP1 & 29 & 100 & RK-ASPEN & Isentropic efficiency 0.9 \\
\hline Methanol Pump & PUMP2 & 32 & 100 & RK-ASPEN & Isentropic efficiency 0.9 \\
\hline Heater & HX1 & 350 & 100 & RK-ASPEN & Outlet temperature $350^{\circ} \mathrm{C}$ \\
\hline Reactor & R-SPC & 350 & 100 & RK-ASPEN & Stoichiometric reactor, 0.95 conversion \\
\hline Flash Separator & FLASH & 100 & 1 & UNIF-LL & Two outlet flash drum \\
\hline \multirow[t]{2}{*}{ Distillation Column } & COLUMN (Top) & 62.5 & 0.8 & UNIF-LL & 10 stages, feed at stage 4 , reflux \\
\hline & COLUMN (Bottom) & 94.5 & 1 & UNIF-LL & ratio 1.5 , distillate to feed ratio 0.7 \\
\hline
\end{tabular}

\subsection{Solar Collectors and Solar Thermal Energy Storage}

A fraction of the energy supply for the biodiesel production processes was obtained from solar energy. Although the thermal loads and energy exchange temperatures for the alkaline and supercritical processes were different, both operate above $100{ }^{\circ} \mathrm{C}$, as well as the process temperatures at which the energy exchange would take place.

The HTF must be raised above the process's temperatures until a stable temperature can be reached and heat exchange can be achieved. The solar technology selected was parabolic trough collectors; this type of solar technology was widely used for electricity generation, as it manages to raise the temperatures of the fluids above $400{ }^{\circ} \mathrm{C}[39,40]$. The thermal energy storage system requires controls to operate continuously and with the minimum variation in temperature at the outlet of the HTF. Due to the solar resource varies, different outflows were defined for tanks 1 and 2. In this way, the HTF necessary for the continuous operation of the biodiesel process was brought to the appropriate temperature in 8 hours. Figure 2 shows the general diagram of the solar energy collection and storage system for each of the processes. 


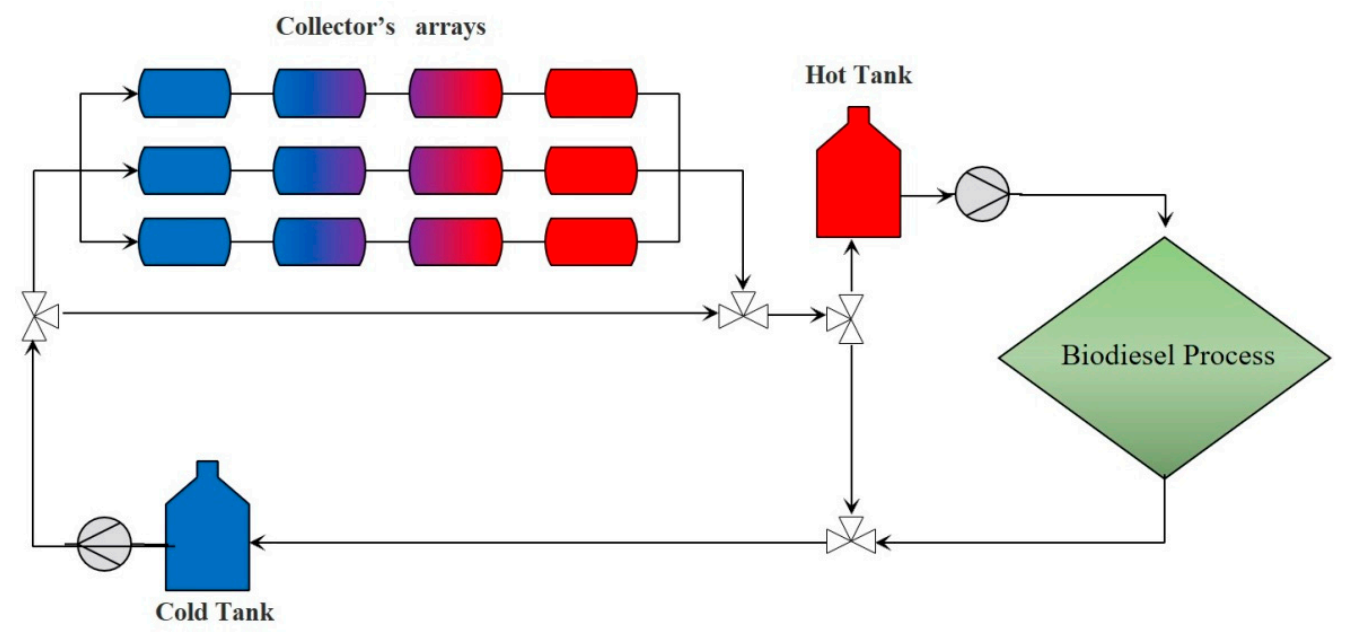

Figure 2. Schematic diagram of solar energy collection system.

The final selection of the collector arrangement was made based on the analysis of the variation in the annual solar fraction concerning different arrangements of solar collectors. The solar fraction is a parameter commonly used in the design and optimization of solar energy collection systems [41,42]. The solar fraction is a better indicator of the performance of a solar energy system than other parameters such as the efficiency of the collectors or the heat removed factor since it shows the overall performance of the system and not of an individual component [43]. The solar fraction is described as the ratio of solar energy input between the total energy required by the process to which it was applied, according to Equation (4).

$$
f=\frac{\dot{Q}_{s}}{\dot{Q}_{s}-\dot{Q}_{a u x}}
$$

where $f$ is the solar fraction, $Q_{s}$ is the heat contributed by solar energy to the process, and $\dot{Q}_{a u x}$ is the required auxiliary thermal energy. As the solar fraction increases in a solar energy system, less is the amount of fossil energy used for auxiliary heating [44].

\subsection{Energy and Exergy Balance}

The energy and exergy analyses of both processes studied in this work consider compliance with the basic principles of conservation of mass and energy, as well as the principle of increasing entropy and destruction of exergy. These principles are reflected in Equations (5)-(8).

$$
\begin{aligned}
& \sum_{i} \dot{m}_{i \text { in }}=\sum_{i} \dot{m}_{\text {iout }} \quad \text { Mass } \\
& \dot{Q}_{i n}+\dot{W}_{\text {in }}+\sum_{i} \dot{m}_{i}\left(h_{i}+\frac{V_{i}^{2}}{2}+g z_{i}\right)_{\text {in }}=\sum_{i} \dot{m}_{i}\left(h_{i}+\frac{V_{i}^{2}}{2}+g z_{i}\right)_{\text {out }}+\dot{Q}_{\text {out }}+\dot{W}_{\text {out }} \quad \text { Energy } \\
& \dot{S}_{g}=\sum_{i} \dot{m}_{i}\left(s_{i}\right)_{o u t}-\sum_{i} \dot{m}_{i}\left(s_{i}\right)_{\text {in }}+\sum_{i} \frac{\dot{Q}_{i}}{T_{0}} \quad \text { Entropy } \\
& \dot{X}_{\text {des }}=\left(\dot{X}_{\text {mass }}\right)_{\text {in }}-\left(\dot{X}_{\text {mass }}\right)_{\text {out }}+\dot{X}_{Q}-\dot{X}_{W} \quad \text { Exergy }
\end{aligned}
$$

The mass exergy of the streams entering and leaving the system consists of four specific forms of exergy and is the sum of the physical, chemical, potential, and kinetic exergy as shown in Equation (9).

$$
\dot{X}_{\text {mass }}=\dot{X}_{\text {phy }}+\dot{X}_{c h}+\dot{X}_{\text {pot }}+\dot{X}_{k i n} \quad \text { Mass Exergy }
$$

Both potential and kinetic energies and exergies were neglected because the changes in position and velocity of the streams involved are not significant enough. The physical and chemical exergies depend on the temperature, enthalpy, entropy, and free energy of the substance in question and are shown below in Equations (10) and (11). 


$$
\begin{gathered}
\dot{X}_{p h y}=\left(\dot{h}-\dot{h}_{0}\right)-T_{0}\left(\dot{s}-\dot{s}_{0}\right) \quad \text { Physical Exergy } \\
\dot{X}_{c h}=\dot{\Delta} G_{f}+\sum_{i} n_{i}\left(\dot{E} x_{c h, i}\right) \quad \text { Chemical Exergy }
\end{gathered}
$$

The exergy transferred by flows of heat and work was determined from Equations (12) and (13).

$$
\begin{gathered}
\dot{X}_{Q}=\left(1-\frac{T_{0}}{T}\right) \dot{Q} \text { Heat flow Exergy } \\
\dot{X}_{W}=\dot{W} \text { Work flow Exergy }
\end{gathered}
$$

In the case of solar collectors, the exergy transmitted by heat was determined from the Petela-Landsberg-Press Equation (14) [45].

$$
\dot{X}_{Q}=\dot{Q}_{s}\left(1-\frac{4}{3} \cdot\left(\frac{T_{\propto}}{T_{\text {sun }}}\right)+\frac{1}{3} \cdot\left(\frac{T_{\propto}}{T_{\text {sun }}}\right)^{4}\right)
$$

\section{Results and Discussion}

Both processes were designed to operate with a supply of $100 \mathrm{~kg} / \mathrm{h}$ of WVO and have a partial source of energy through solar thermal energy. These two different reaction

\begin{tabular}{|c|c|c|c|c|c|c|c|c|c|c|c|c|}
\hline STREAM NAME & WVO & SULF-AC1 & AOH-1 & AOH-2 & NAOH & 11 & 13 & S4 & B-DIESEL & S5 & GLYCEROL & AOH-REC \\
\hline Temperature $\left({ }^{\circ} \mathrm{C}\right)$ & 25 & 25 & 25 & 25 & 25 & 50 & 65 & 30 & 120 & 120 & 105.4 & 58.7 \\
\hline Pressure (bar) & 1 & 1 & 1 & 1 & 1 & 2 & 2 & 2 & 1 & 1 & 1 & 0.8 \\
\hline Mass Flows $(\mathrm{kg} / \mathrm{h})$ & 100.0 & 0.4 & 16.1 & 20.0 & 1.0 & 116.5 & 137.5 & 170.7 & 101.8 & 68.8 & 14.1 & 25.2 \\
\hline \multicolumn{13}{|l|}{ Mass Fractions } \\
\hline Triolein & 0.930 & 0.000 & 0.000 & 0.000 & 0.000 & 0.759 & 0.032 & 0.025 & 0.043 & 0.000 & 0.005 & 0.000 \\
\hline Oleic Acid & 0.070 & 0.000 & 0.000 & 0.000 & 0.000 & 0.003 & 0.003 & 0.002 & 0.003 & 0.000 & 0.003 & 0.000 \\
\hline Methanol & 0.000 & 0.000 & 1.000 & 1.000 & 0.000 & 0.127 & 0.187 & 0.033 & 0.000 & 0.082 & 0.039 & 0.997 \\
\hline Water & 0.000 & 0.000 & 0.000 & 0.000 & 0.000 & 0.004 & 0.003 & 0.382 & 0.021 & 0.915 & 0.107 & 0.003 \\
\hline Methyl Oleate & 0.000 & 0.000 & 0.000 & 0.000 & 0.000 & 0.100 & 0.698 & 0.540 & 0.904 & 0.002 & 0.279 & 0.000 \\
\hline Glycerol & 0.000 & 0.000 & 0.000 & 0.000 & 0.000 & 0.004 & 0.067 & 0.014 & 0.022 & 0.001 & 0.494 & 0.000 \\
\hline Sulfuric Acid & 0.000 & 1.000 & 0.000 & 0.000 & 0.000 & 0.003 & 0.003 & 0.001 & 0.002 & 0.000 & 0.012 & 0.000 \\
\hline Sodium Hydroxide & 0.000 & 0.000 & 0.000 & 0.000 & 1.000 & 0.000 & 0.007 & 0.003 & 0.005 & 0.000 & 0.001 & 0.000 \\
\hline Sodium Sulfate & 0.000 & 0.000 & 0.000 & 0.000 & 0.000 & 0.000 & 0.000 & 0.000 & 0.000 & 0.000 & 0.062 & 0.000 \\
\hline
\end{tabular}
pathways for biodiesel production entail diverse challenges and implications that directly impact the design and implementation of the process, including the solar collection system. The simulation results for both process streams can be seen in Tables 2 and 3.

Table 2. Operating conditions and mass compositions of simulation streams. Alkaline process.

The alkaline catalyst biodiesel production process reached a global yield of $91.3 \%$, with a production of $101.85 \mathrm{~kg} / \mathrm{h}$ of biodiesel. Although, the supercritical conditions process produces $102.5 \mathrm{~kg} / \mathrm{h}$ of biodiesel with a global yield of $98.9 \%$. The difference in the performance of both processes is due to the absence of catalysts in the supercritical process, which facilitates the separation of biodiesel from the reaction products, and the by-product $1,2,3$ trimethyl glycerol triether is part of the biofuel.

An exhaustive bibliographic review was carried out and did not find studies that could be globally compared with the results obtained since there are no processes that fully fit the proposed work. A comparison was made between typical sections of the processes.

In order to validate the biodiesel production process, it was decided to evaluate the performance of the transesterification reactor. Although this unit is standard in biodiesel production processes, the specific data obtained at the outlet of the reactor under supercritical conditions were less reported. 
Table 3. Operating conditions and mass compositions of simulation streams. Supercritical Process.

\begin{tabular}{|c|c|c|c|c|c|c|c|}
\hline STREAM NAME & WVO & $\mathrm{AOH}$ & 5 & 6 & B-DIESEL & 7 & 10 \\
\hline Temperature $\left({ }^{\circ} \mathrm{C}\right)$ & 30 & 30 & 350 & 350 & 100 & 100 & 62 \\
\hline Pressure (bar) & 1 & 1 & 100 & 100 & 1 & 1 & 1 \\
\hline Mass Flows (kg/h) & 100.0 & 39.6 & 139.6 & 139.6 & 102.6 & 37.0 & 19.9 \\
\hline \multicolumn{8}{|l|}{ Mass Fractions } \\
\hline Water & 0.000 & 0.000 & 0.000 & 0.043 & 0.001 & 0.160 & 0.152 \\
\hline Triolein & 0.930 & 0.000 & 0.666 & 0.013 & 0.018 & 0.000 & 0.000 \\
\hline Methanol & 0.000 & 1.000 & 0.284 & 0.136 & 0.008 & 0.492 & 0.848 \\
\hline Oleic Acid & 0.070 & 0.000 & 0.050 & 0.001 & 0.001 & 0.000 & 0.000 \\
\hline Methyl Oleate & 0.000 & 0.000 & 0.000 & 0.707 & 0.963 & 0.000 & 0.000 \\
\hline Trimethyl Glycerol Triether & 0.000 & 0.000 & 0.000 & 0.099 & 0.009 & 0.348 & 0.000 \\
\hline
\end{tabular}

In Table 4, a validation of the biodiesel production results is presented, specifically at the output of the transesterification reactor of similar processes.

Table 4. Validation of the outflow stream of transesterification reactor.

\begin{tabular}{|c|c|c|c|c|c|}
\hline & \multicolumn{3}{|c|}{ ALKALINE PROCESS } & \multicolumn{2}{|c|}{ SUPERCRITICAL PROCESS } \\
\hline & CURRENT STUDY & [30] & [11] & CURRENT STUDY & [38] \\
\hline Stream Name & 13 & 10 & 116 & 6 & 10 \\
\hline Temperature $\left({ }^{\circ} \mathrm{C}\right)$ & 65 & 60 & 60 & 350 & 400 \\
\hline Pressure (bar) & 2 & 4 & 4 & 100 & 200 \\
\hline Mass Flows (kg/h) & 137.5 & 1289.83 & 1278.08 & 139.6 & 1726.6 \\
\hline Process Yield (\%) & 92.04 & 94.42 & 96.5 & 98 & 97 \\
\hline \multicolumn{6}{|l|}{ Mass Fractions } \\
\hline Triolein & 0.032 & 0.0407 & 0.0229 & 0.018 & 0.004 \\
\hline Oleic Acid & 0.003 & - & 0 & 0.001 & - \\
\hline Methanol & 0.187 & 0.0942 & 0.096 & 0.136 & 0.091 \\
\hline Water & 0.003 & 0 & 0 & 0.043 & 0.051 \\
\hline Methyl Oleate & 0.698 & 0.7769 & 0.7961 & 0.707 & 0.742 \\
\hline Glycerol & 0.067 & 0.0804 & 0.771 & - & - \\
\hline Sulfuric Acid & 0.003 & 0 & 0 & - & - \\
\hline Sodium Hydroxide & 0.007 & 0.0078 & 0.0078 & - & - \\
\hline Sodium Sulfate & 0.000 & 0 & 0 & - & - \\
\hline $\begin{array}{l}\text { Trimethyl Glycerol } \\
\text { Triether }\end{array}$ & - & - & - & 0.099 & 0.112 \\
\hline
\end{tabular}

Different equipment and stages in biodiesel production require different amounts of mechanical and thermal energy, the latter for both cooling and heating. The alkaline biodiesel process, although it is one of the most widely used commercial methods, it implies more operations for the process and greater consumption of energy, based on the current work. Figure 3 shows the energy loads required for both processes in the main stages.

The difference in the energy load required for each process lies in different stages. The alkaline process requires $53.78 \mathrm{~kW}$ of heating for the biodiesel purification stage, as shown in Figure 3A. Meanwhile, the highest energy demand for the supercritical process is found in the reaction stage, specifically in the heating to reach the appropriate temperature conditions for the reaction, requiring $38.80 \mathrm{~kW}$. 


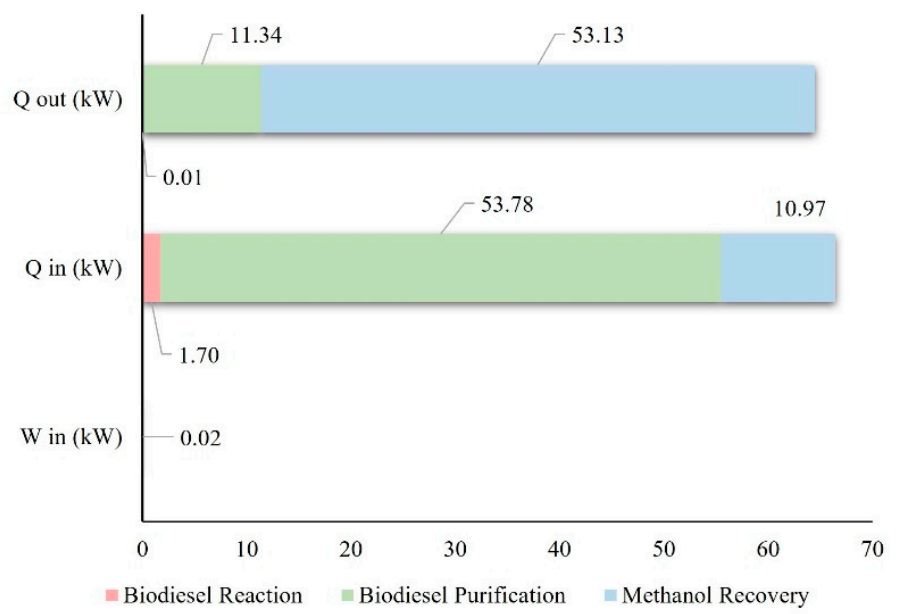

(A)

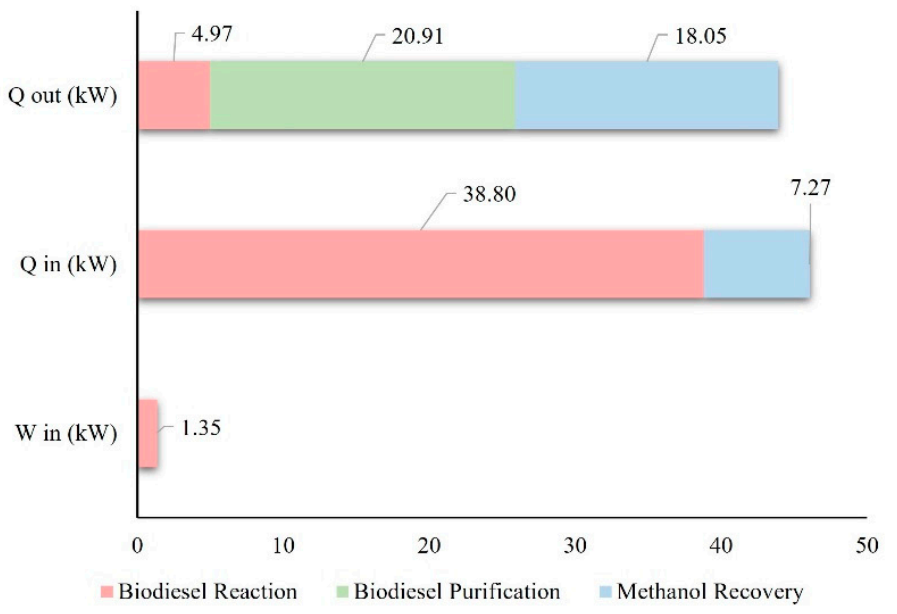

(B)

Figure 3. Energy loads of the main stages of the biodiesel production processes. (A) Alkaline process, (B) Supercritical process.

Based on the operating conditions and thermal energy demands of each process, a system of solar collectors was structured to supply solar thermal energy to fulfill the energy demands. Table 5 presents the solar collection system required for each process.

Table 5. Parameters of the array of parabolic trough collectors for each process.

\begin{tabular}{lcc}
\hline \multicolumn{1}{c}{ PARAMETER } & ALKALINE PROCESS & SUPERCRITICAL PROCESS \\
\hline Collectors in series & 4 & 6 \\
Collectors in parallel & 8 & 13 \\
Individual collection area & $10 \mathrm{~m}^{2}$ & $10 \mathrm{~m}^{2}$ \\
Total collection area & $320 \mathrm{~m}^{2}$ & $780 \mathrm{~m}^{2}$ \\
Azimuth orientation & $0^{\circ}$ & $0^{\circ}$ \\
Tilt & Solar tracking on a single axis & Solar tracking on a single axis
\end{tabular}

According to a previous research [34], the number of collectors in the array influences the overall energy efficiency of the process. However, at processes with temperature requirements below $400{ }^{\circ} \mathrm{C}$ and with an arrangement of more than 6 collectors in series and 13 in parallel, the increase in efficiency is marginal while reducing the economic viability of the project. The solar collector system structured for the alkaline biodiesel production process delivers only the thermal energy required by the Flash separation equipment, an essential part of biodiesel purification. The energy supplied by solar energy in this process is approximately $81 \%$, while for the process under supercritical conditions, it is only possible to provide $74.5 \%$. For the process under supercritical conditions, the energy is provided for preheating the reactants and as a support of the distillation reboiler column at the methanol recovery stage. The operating temperature of each process is the main reason for the difference in the total collection area for each one. The supercritical process operates at temperatures above $200{ }^{\circ} \mathrm{C}$. Therefore, the number of solar collectors required in series and parallel increases to maintain a constant supply of HTF at a stable temperature, suitable for energy transfer to the process.

Although both processes have different equipment and energy loads, analyses of the first and second laws of thermodynamics were performed to optimize the use of energy. The biodiesel production process and the solar collection system were accounted as the same process for these analyses. 
Considering that the first law analysis is an energy analysis of the process, the energy efficiency for each one was determined using Equation (15), as well as the energy invested per kilogram of biofuel produced according to Equation (16).

$$
\begin{gathered}
\eta_{I}=\frac{\dot{m}_{\text {biodiesel }} \cdot L H V_{\text {biodiesel }}}{\dot{m}_{W V O} \cdot L H V_{W V O}+\dot{Q}_{P T C}+\dot{Q}_{A u x}+\dot{W}_{\text {in }}} \\
E C R_{\text {bio }}=\frac{\dot{E}_{\text {in total }}}{\dot{m}_{\text {biodiesel }}}
\end{gathered}
$$

The first law energy efficiency was $91.64 \%$ for the process under supercritical conditions and $88.59 \%$ for the alkaline route. These results were because producing biodiesel by the alkaline route requires a higher amount of thermal energy to separate the biofuel. The energy of the raw material concerning the product is relatively the same for both processes. The transfer conditions for the thermal energy supply influence the efficiency with which these energies are used. The use of solar energy supposes energy savings because of the partial supply of energy. However, the process under supercritical conditions consumes more energy with $737.9 \mathrm{~kJ}$ per $\mathrm{kg}$ of biodiesel produced than the alkaline catalysis process with $454.5 \mathrm{~kJ}$ per $\mathrm{kg}$ of biodiesel.

Estimating the exergy destruction enables identifying the points in the process where the energy is not being used optimally or in general to identify which process has greater irreversibilities.

For the exergy balance, the chemical exergy of each stream was calculated from the chemical exergy of each species, multiplied for its mass fraction in the flow. Table 6 shows the chemical exergies of the species involved in the processes. The chemical exergies of the species used in the simulations were similar to the values reported in the literature.

\begin{tabular}{|c|c|c|c|c|c|}
\hline SUBSTANCE & FORMULA & MW (kg/kmol) & $\Delta \mathrm{G}^{\circ}(\mathrm{kJ} / \mathrm{kmol})$ & $E x_{\text {ch }}(k J / k g)$ & REPORTED Ex $_{\mathrm{ch}}(\mathrm{kJ} / \mathrm{kg})$ \\
\hline Methanol & $\mathrm{CH}_{3} \mathrm{OH}$ & 32.0 & $-162,320$ & $22,536.8$ & $22,360[46]$ \\
\hline Triolein & $\mathrm{C}_{57} \mathrm{H}_{104} \mathrm{O}_{6}$ & 885.4 & $-34,480$ & $40,252.4$ & $39,930[46]$ \\
\hline Sodium Hydroxide & $\mathrm{NaOH}$ & 40.0 & $-379,494$ & 1931.2 & $1872.5[47]$ \\
\hline Methyl Oleate & $\mathrm{C}_{19} \mathrm{H}_{36} \mathrm{O}_{2}$ & 296.5 & $-44,600$ & $40,486.0$ & $39,790[46]$ \\
\hline Glycerol & $\mathrm{C}_{3} \mathrm{H}_{8} \mathrm{O}_{3}$ & 92.1 & $-438,520$ & $18,923.0$ & $18,670[46]$ \\
\hline Oleic Acid & $\mathrm{C}_{18} \mathrm{H}_{34} \mathrm{O}_{2}$ & 282.5 & $-84,840$ & $40,062.0$ & - \\
\hline Sulfuric Acid & $\mathrm{H}_{2} \mathrm{SO}_{4}$ & 98.1 & $-793,060$ & 1666.0 & $1667[47]$ \\
\hline Water & $\mathrm{H}_{2} \mathrm{O}$ & 18.0 & $-237,100$ & 54.7 & $52.77[47]$ \\
\hline Biphenyl & $\mathrm{C}_{12} \mathrm{H}_{10}$ & 154.2 & 274,980 & $41,363.1$ & - \\
\hline Biphenyl Ether & $\mathrm{C}_{12} \mathrm{H}_{10} \mathrm{O}$ & 170.2 & 169,980 & $36,869.7$ & - \\
\hline $\begin{array}{l}\text { Trimethyl Glycerol } \\
\text { Triether }\end{array}$ & $\mathrm{C}_{6} \mathrm{H}_{14} \mathrm{O}_{3}$ & 134.2 & $-317,800$ & $28,340.3$ & - \\
\hline Sodium Sulfate & $\mathrm{Na}_{2} \mathrm{SO}_{4}$ & 142.0 & $-1268,696$ & 100.7 & - \\
\hline
\end{tabular}

Table 6. Chemical Exergy for all the chemical species in the process.

The physical exergy of each stream was obtained from Aspen Plus ${ }^{\circledR}$, and the exergetic balance was performed in Excel ${ }^{\circledR}$. For the global exergetic efficiency of each process, Equation (17) was used:

$$
\eta_{I I}=1-\frac{\dot{X}_{\text {des }}}{\dot{X}_{\text {in }}}=1-\frac{\dot{X}_{\text {des }}}{\dot{X}_{\text {mass, in }}+\dot{X}_{Q \text { solar }}+\dot{X}_{Q \text { Aux }}+\dot{X}_{W}}
$$

Figure 4 presents the global exergy balance for each process.

In Table 7, a validation of the exergy analysis for the biodiesel production results is presented, compared to similar processes. 


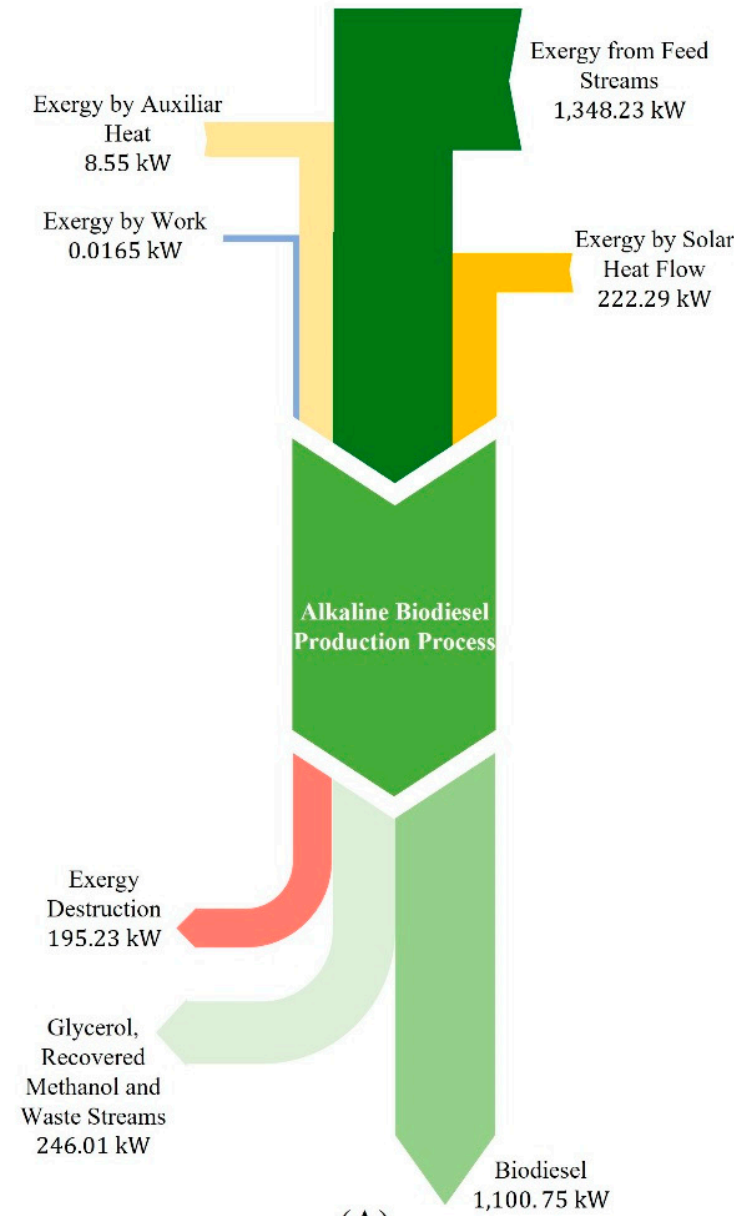

(A)

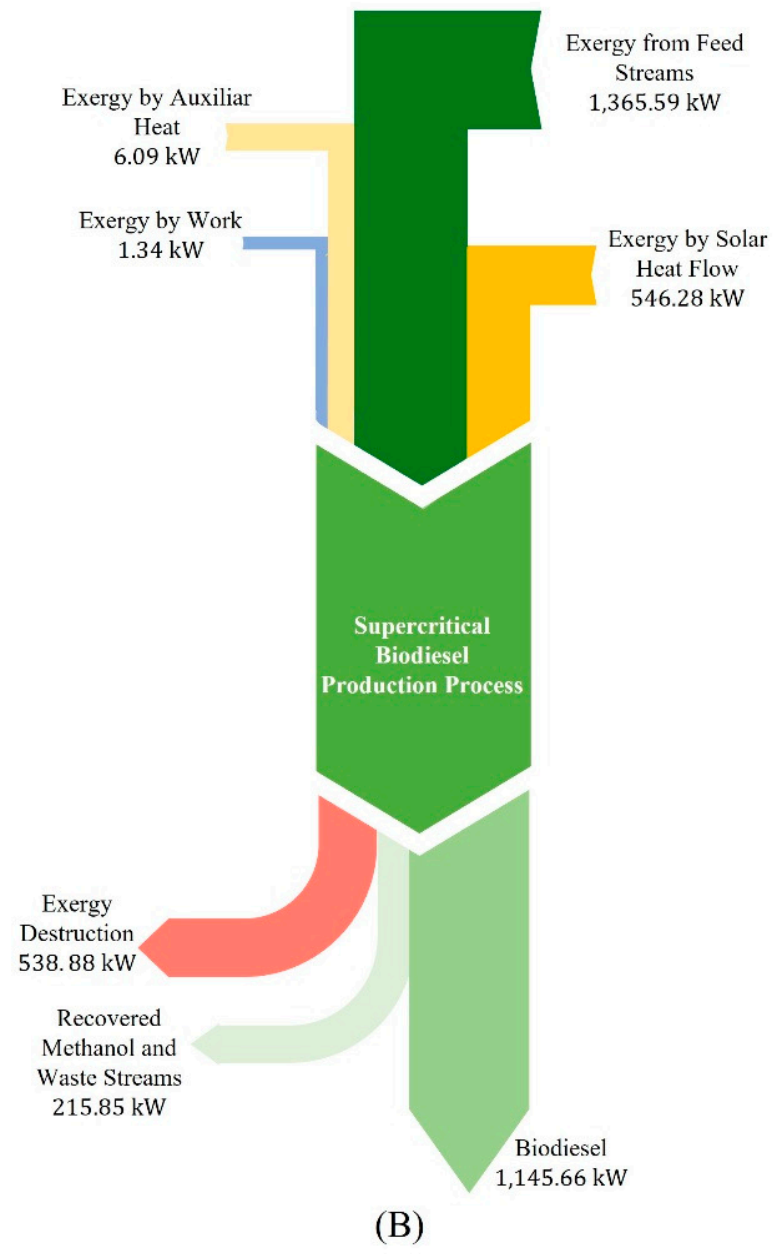

(B)

Figure 4. Sankey diagram of the global exergy balance for each process. (A) Alkaline process, (B) Supercritical process.

Table 7. Exergy analysis validation.

\begin{tabular}{|c|c|c|c|c|c|c|}
\hline & \multicolumn{3}{|c|}{ ALKALINE PROCESS } & \multicolumn{3}{|c|}{ SUPERCRITICAL PROCESS } \\
\hline & CURRENT STUDY & [30] & {$[48]$} & CURRENT STUDY & [49] & [50] \\
\hline Feedstock & WVO & Triolein & WVO & WVO & Palm Oil & Soybean Oil \\
\hline Main Energy Source & Solar & Solar & Fossil & Solar & Fossil & Fossil \\
\hline Biodiesel Production $(\mathrm{kg} / \mathrm{h})$ & 92 & 991.4 & 93.096 & 98.74 & 9145 & 1004 \\
\hline Energy Requirement (kW) & 66.46 & 342.4 & 131.1 & 47.41 & - & - \\
\hline Process Yield (\%) & 92.04 & 94.42 & $75.6-90.2$ & 98 & 98 & 95.6 \\
\hline $\begin{array}{l}\text { Exergy Out } \\
\left(\mathrm{kWh} / \mathrm{kg}_{\text {biodiesel }}\right)\end{array}$ & 11.92 & 11.05 & 10.78 & 11.6 & 73.15 & - \\
\hline $\begin{array}{l}\text { Exergy Destruction } \\
\left(\mathrm{kWh} / \mathrm{kg}_{\text {biodiesel }}\right)\end{array}$ & 2.12 & 4.88 & $1.31-2.33$ & 5.45 & 3.24 & - \\
\hline $\begin{array}{l}\text { Overall Exergy } \\
\text { Efficiency (\%) }\end{array}$ & 85.2 & 74.3 & $89.6-91.7$ & 70.9 & 82.4 & 93.5 \\
\hline
\end{tabular}


The processes contrasted with the present study imply different production capacities and process designs; for that reason, there are significant differences in the energy requirements, irreversibilities, and global exergetic efficiency of the process. However, the operating conditions and production method are equivalent to the simulated processes.

In the case of the process under supercritical conditions, few exergy studies were reported with the level of detail that allows a better comparison of the performed analysis. An important characteristic that influences exergetic efficiency is the process energy source. For the present study, solar energy as the foremost source represents the top influence on exergy destruction and exergetic efficiency.

The process at supercritical conditions exhibits high irreversibility with $538.88 \mathrm{~kW}$ of wasted useful energy and an overall exergetic efficiency of 70.9\%. Meanwhile, the exergetic efficiency of the alkaline process was $85.2 \%$, with only $195.23 \mathrm{~kW}$ of exergy destruction, thus having a more efficient use of the available exergy. Both processes present their highest exergy loss in the solar thermal energy collection system due to the large amount of solar energy that reaches the collectors, and it is not fully utilized. If the exergy losses contributed by the collector system are ignored, and only the exergy losses in the biodiesel production process are considered, it is possible to identify the stages with the highest irreversibilities. Figure 5 illustrates the contribution of each operation to exergy destruction in each process.

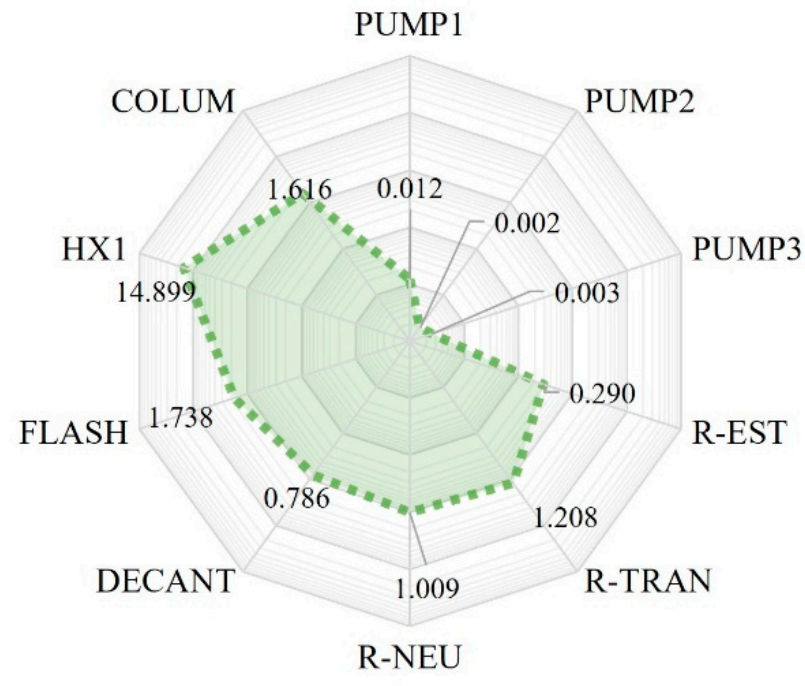

(A)

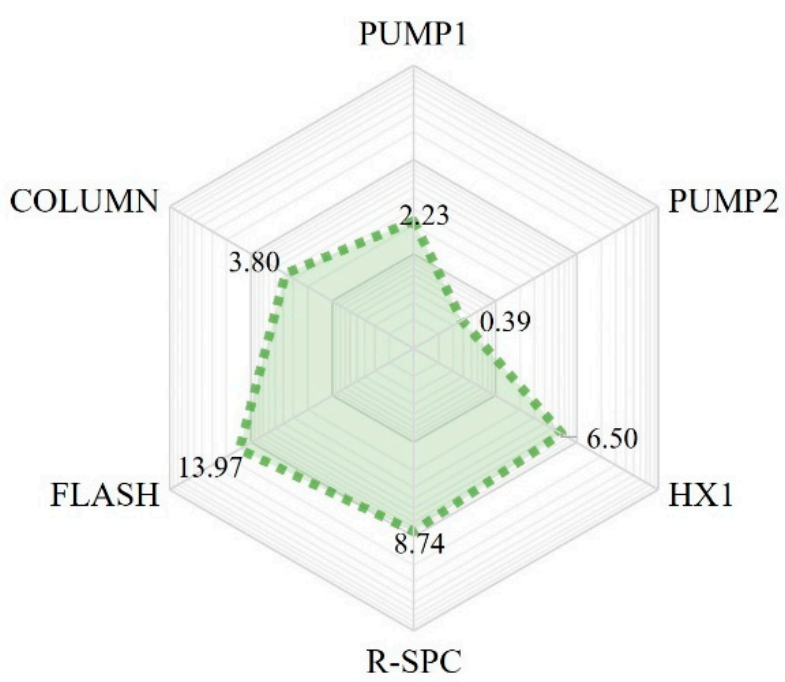

(B)

Figure 5. Exergy destruction by operation in each biodiesel production process (kW). (A) Alkaline process, (B) Supercritical process.

The supercritical process continues to have greater irreversibility, considering only the exergy losses of the biodiesel production process. The stage with the highest exergy destruction in this process is the biodiesel reaction stage. It involves the transference of a large amount of thermal energy, representing 50.12\% of the exergy destroyed in this stage, followed by the purification stage with 39\%. Regarding the alkaline process, the greatest exergy destruction corresponds to the methanol recovery stage, contributing $81 \%$ of the irreversibilities. Although the highest energy load for this process occurs in the purification stage, the methanol recovery stage involves the condensation of a stream, which means the release of a significant amount of thermal energy.

Since solar energy is the main source of energy for these processes, the effect of the variation in the solar exergy was analyzed and compared with the exergy destruction and with the second law efficiency. The operation of the process on a typical summer day in Mexicali, Baja California, Mexico, is depicted in Figure 6. 


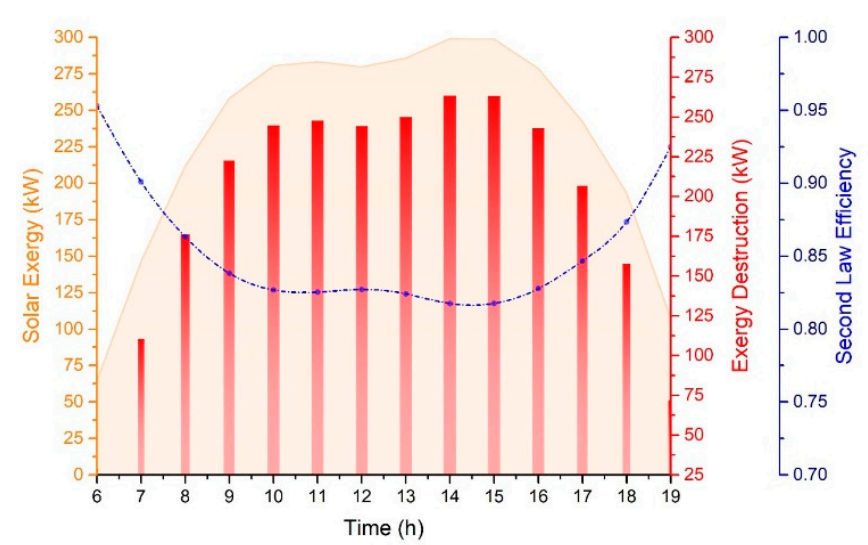

(A)

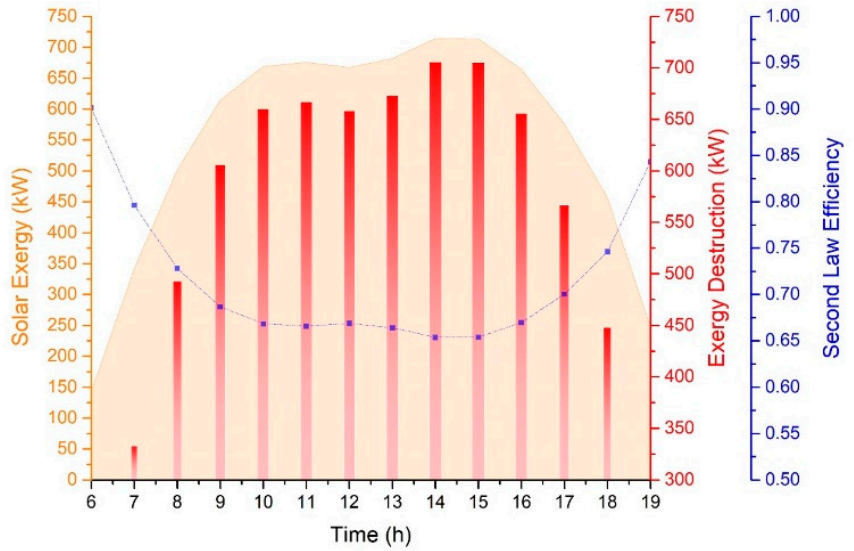

(B)

Figure 6. Variation in exergy destruction and exergetic efficiency with respect to solar exergy on a typical average summer day. (A) Alkaline process, (B) Supercritical process.

In both processes, the exergy provided by the solar resource varies depending on the radiation transition during the day. The destruction of exergy for both processes is mainly contributed by solar exergy. As the solar exergy increases, so does the destruction of the exergy, decreasing the efficiency of the second law, which depends on the input exergy.

\section{Conclusions}

In the present work, the biodiesel production process was studied from the perspective of the first and second thermodynamics laws, using two routes for transesterification of triglycerides and converting them into methyl esters. Both processes were supplied mainly with a renewable energy source such as solar energy through a parabolic trough collector's system. The supercritical process has a higher biodiesel global yield than the alkaline process. However, the high operating temperatures of the supercritical process require a large solar collector system to have a stable temperature in the heat transfer fluid, even though the heating needs of the alkaline process are higher. The solar thermal energy collection system can supply $81 \%$ of the energy required by the alkali process and $74.5 \%$ of the supercritical process. From the energy and exergy analysis, it can be noted that the energy efficiency of the supercritical process is higher. Nevertheless, the exergetic efficiency of the alkaline process is higher than the supercritical one. The alkaline process has an exergetic efficiency of $85.2 \%$. Irreversibilities in the supercritical process is higher and mainly presented as energy losses due to heat transfer. It is essential to identify that high operation temperatures favor this inefficiency, leading to exergy destruction. Solar collection systems contribute from $85 \%$ to $93 \%$ of the exergy destroyed by the global process for both cases. The solar resource is abundant, and it is one of the competitive advantages presented in the proposed processes. The irreversibilities reductions must be centralized in the biodiesel production process itself.

In the supercritical process, the focal source of exergy destruction is in the reaction stage due to the high operating temperatures. This characteristic of the process limits the alternatives to reduce the destroyed exergy in the reaction stage.

The alkaline process presents its greatest irreversibilities in the methanol recovery stage by destroying $14.8 \mathrm{~kW}$ of exergy in the condenser of the distillation column. This exergy could be exploited by using that stream as a preheating source for the same process, thus increasing the energy efficiency of the system. Based on the analyses results, the alkaline biodiesel production process has the highest advantages when using solar energy as the main source of energy, compared to a process in supercritical conditions that present bigger irreversibilities and require more infrastructure to collect the solar resource. Each solar collection system has its limitations due to the intermittency of the solar resource, 
especially in the hours of the day when solar radiation is not enough. However, using solar energy as the foremost energy source offers an alternative to fossil fuels and hence an environmental benefit concurrently with the use of biodiesel.

Author Contributions: Conceptualization, J.A.L. and G.M.; methodology, G.M. and M.A.C.; software, J.A.L.; validation, D.G.M. and J.M.A.; formal analysis, J.R.A.; investigation, D.G.M. and L.Q.; resources, M.A.C. and L.J.P.; data curation, J.R.A. and J.M.A.; writing-original draft preparation, J.A.L. and J.R.A.; writing-review and editing, G.M. and L.J.P.; visualization, D.G.M. and L.Q.; supervision, M.A.C.; project administration, J.A.L. All authors have read and agreed to the published version of the manuscript.

Funding: This research received no external funding.

Institutional Review Board Statement: Not applicable.

Informed Consent Statement: Not applicable.

Data Availability Statement: This manuscript is based on the integration of the results obtained from the simulations developed in the ASPEN PLUS®and TRNSYS®software. The ASPEN PLUS®license agreement signed by the Universidad Autónoma de Baja California states that: "The customer will not transfer all or part of the results of the use of the software". For this reason, access to the data is restricted.

Acknowledgments: All the authors thank the National Council of Science and Technology (CONACYT) and the Engineering Institute of the Universidad Autónoma de Baja California for its support in the development of this work.

Conflicts of Interest: The authors declare that there is no conflict of interest regarding the publication of this paper.

\section{Nomenclature}

$\dot{E} \quad$ Energy transfer flow $[\mathrm{kW}]$

$\dot{X}_{W} \quad$ Work flow exergy [kW]

$\dot{Q} \quad$ Heat transfer flow $[\mathrm{kW}]$

$\dot{X}_{\text {phy }} \quad$ Physical exergy of stream $[\mathrm{kW}]$

$\dot{Q}_{s} \quad$ Solar heat transfer flow [kW]

$\dot{X}_{c h} \quad$ Chemical exergy of stream [kW]

$\dot{Q}_{a u x} \quad$ Auxiliar heat transfer flow [kW]

$\dot{X}_{\text {pot }} \quad$ Potential exergy [kW]

$\dot{W} \quad$ Work transfer flow [kW]

$\dot{X}_{k i n} \quad$ Kinetic exergy [kW]

$\dot{m}_{i} \quad$ Mass flow rate of stream $[\mathrm{kg} / \mathrm{s}]$

$\Delta G_{f} \quad$ Free Gibbs energy of formation $[\mathrm{kJ} / \mathrm{kmol}]$

$h_{i} \quad$ Specific enthalpy of stream $[\mathrm{kJ} / \mathrm{kg}]$

$n_{i} \quad$ Mol number [ $\left.\mathrm{kmol}\right]$

$V_{i} \quad$ Velocity of stream $[\mathrm{m} / \mathrm{s}]$

$\dot{E} x_{c h, i} \quad$ Chemical exergy of substance $[\mathrm{kJ} / \mathrm{kg}]$

$g \quad$ Gravitational acceleration $\left[9.8 \mathrm{~m} / \mathrm{s}^{2}\right]$

MW Molecular weight $[\mathrm{kg} / \mathrm{kmol}]$

$z_{i} \quad$ Height of stream [m]

LHV Lower heating value

$s_{i} \quad$ Specific entropy of stream $[\mathrm{kJ} /(\mathrm{kg} \mathrm{K})]$

$\eta_{I} \quad$ First law efficiency

$\dot{S}_{g} \quad$ Entropy production $[\mathrm{kJ} / \mathrm{K}]$

$\eta_{I I} \quad$ Second law efficiency

$T_{0} \quad$ Reference temperature [K]

$E C R_{\text {bio }} \quad$ Energy consumption rate $[\mathrm{kJ} / \mathrm{kg}]$

$T_{\propto} \quad$ Environmental temperature [K] 


$\begin{array}{ll}\text { WVO } & \text { Waste vegetable oil } \\ T_{\text {sun }} & \text { Sun average temperature }[5778 \mathrm{~K}] \\ \text { FFA } & \text { Free fatty acids } \\ \dot{X} & \text { Exergy transfer flow }[\mathrm{kW}] \\ \text { HTF } & \text { Heat transfer fluid } \\ \dot{X}_{\text {des }} & \text { Exergy destruction }[\mathrm{kW}] \\ \text { PTC } & \text { Parabolic trough collector } \\ \dot{X}_{\text {mass }} & \text { Mass exergy }[\mathrm{kW}] \\ f & \text { Solar fraction } \\ \dot{X}_{Q} & \text { Heat flow exergy }[\mathrm{kW}]\end{array}$

\section{References}

1. Gebresilassie, A.E.; Morken, J.; Lekang, O.L.; Yigezu, Z.D. Factors affecting the potential of Jatropha curcas for sustainable biodiesel. Renew. Sustain. Energy Rev. 2020, 137, 110500. [CrossRef]

2. Hakimelahib, A.; Krishna, K.V.R.; Dhingra, S.L.; Peiravian, F. Updating of a Travel Demand Model Based on Fuel Consumption Data. Transp. Res. Procedia 2020, 48, 1401-1417. [CrossRef]

3. Kumar, K.R.; Krishna, C.N.V.V.; Kumar, N.S. Solar Thermal Energy Technologies and its Applications for Process Heating and Power Generation-A Review. J. Clean. Prod. 2021, 282, 125296. [CrossRef]

4. Su, Z.; Zhang, M.; Xu, P.; Zhao, Z.; Wang, Z.; Huang, H.; Ouyang, T. Opportunities and strategies for multigrade waste heat utilization in various industries: A recent review. Energy Convers. Manag. 2021, 229, 113769. [CrossRef]

5. Amelio, A.; Van de Voorde, T.; Creemers, C.; Degreve, J.; Darvishmanesh, S.; Luis, P.; Van der Bruggen, B. Comparison between exergy and energy analysis for biodiesel production. Energy 2016, 98, 135-145. [CrossRef]

6. Mexico Secretary of Energy. National Energy Balance. 2019. Available online: https://www.gob.mx/cms/uploads/attachment/ file/618408/20210218_BNE.pdf (accessed on 9 December 2021).

7. Kallas, K.; Gil, J.M. Do the Spanish want biodiesel? A case study in the Catalan transport sector. Renew. Energy 2015, 83, 395-406. [CrossRef]

8. Castro, N.F. International experiences with the cultivation of Jatropha curcas for biodiesel production. Energy 2016, 112, 1245-1258 [CrossRef]

9. Chavan, S.B.; Yadav, M.; Singh, R.; Singh, V.; Kumbhar, R.R.; Sharma, Y.C. Production of Biodiesel from Three Indigenous Feedstock: Optimization of Process Parameters and Assessment of Various Fuel Properties. Environ. Prog. Sustain. Energy 2017, 36, 788-795. [CrossRef]

10. Jegannathan, K.R.; Eng-Seng, C.; Ravindra, P. Economic assessment of biodiesel production: Comparison of alkali and biocatalyst processes. Renew. Sustain. Energy Rev. 2011, 15, 745-751. [CrossRef]

11. Ziyai, M.R.; Mehrpooya, M.; Aghbashlo, M.; Omid, M.; Alsagri, A.S.; Tabatabaei, M. Techno-economic comparison of three biodiesel production scenarios enhanced by glycerol supercritical water reforming process. Int. J. Hydrogen Energy 2019, 44, 17845-17862. [CrossRef]

12. Kalu-Uka, G.M.; Kumar, S.; Kalu-Uka, A.C.; Vikram, S.; Okorafor, O.O.; Kigozi, M.; Ihekweme, G.O.; Onwualu, A.P. Prospects for biodiesel production from Macrotermes nigeriensis: Process optimization and characterization of biodiesel properties. Biomass Bioenergy 2021, 146, 105980. [CrossRef]

13. Ang, G.T.; Tan, K.T.; Lee, K.T. Recent development and economic analysis of glycerol-free processes via supercritical fluid transesterification for biodiesel production. Renew. Sustain. Energy Rev. 2014, 31, 61-70. [CrossRef]

14. Botti, R.F.; Innocentini, M.D.M.; Faleiros, T.A.; Mello, M.F.; Flumignan, D.L.; Santos, L.K.; Franchin, G.; Colombo, P. Biodiesel Processing Using Sodium and Potassium Geopolymer Powders as Heterogeneous Catalysts. Molecules 2020, 25, 2839. [CrossRef] [PubMed]

15. Goli, J.; Sahu, O. Development of heterogeneous alkali catalyst from waste chicken eggshell for biodiesel production. Renew. Energy 2018, 128, 142-154. [CrossRef]

16. Makareviciene, V.; Sendzikiene, E. Noncatalytic Biodiesel Synthesis under Supercritical Conditions. Processes 2021, 9, 138. [CrossRef]

17. Gupta, A.K.; Jalan, A.P.; Rathod, V.K. Solar energy as a process intensification tool for the biodiesel production from hempseed oil. Energy Convers. Manag. 2018, 171, 126-132. [CrossRef]

18. Agee, B.M.; Mullins, G.; Swartling, D.J. Use of solar energy for biodiesel production and use of biodiesel waste as a green reaction solvent. Sustain. Chem. Process. 2014, 2, 21. [CrossRef]

19. Mihankhah, T.; Delnavaz, M.; Khaligh, N.G. Eco-friendly biodiesel production from olive oil waste using solar energy. Energy Sources Part A Recovery Util. Environ. Eff. 2016, 38, 3668-3672. [CrossRef] 
20. Naveen, S.; Gopinath, K.P.; Malolan, R.; Jayaraman, R.S.; Aakriti, K.; Arun, J. Novel Solar Parabolic Trough Collector cum Reactor for the Production of Biodiesel from Waste Cooking Oil using Calcium Oxide catalyst derived from seashells waste. Chem. Eng. Process.-Process Intensif. 2020, 157, 108145. [CrossRef]

21. Sarabchi, N.; Yari, M.; Mahmoudi, S.M.S. Exergy and exergoeconomic analyses of novel high-temperature proton exchange membrane fuel cell based combined cogeneration cycles, including methanol steam reformer integrated with catalytic combustor or parabolic trough solar collector. J. Power Sources 2021, 485, 229-277. [CrossRef]

22. Chaudhary, V.; Gakkha, R. Exergy based performance comparison of DI diesel engine fuelled with WCO15 and NEEM15 biodiesel. Environ. Prog. Sustain. Energy 2019, 39, e13363. [CrossRef]

23. Panigrahi, N.; Mohanty, M.K.; Mishra, S.R.; Mohanty, R.C. Energy and Exergy Analysis of a Diesel Engine Fuelled with Diesel and Simarouba Biodiesel Blends. J. Inst. Eng. Ser. C 2018, 99, 9-17. [CrossRef]

24. Murugapoopathi, S.; Vasudevan, D. Energy and exergy analysis on variable compression ratio multi-fuel engine. J. Therm. Anal. Calorim. 2019, 136, 255-266. [CrossRef]

25. Yildiz, I.; Caliskan, H.; Mori, K. Energy, exergy and environmental assessments of biodiesel and diesel fuels for an internal combustion engine using silicon carbide particulate filter. J. Therm. Anal. Calorim. 2021, 145, 739-750. [CrossRef]

26. Jaimes, W.; Acevedo, P.; Kafarov, V. Comparison of technology alternative for palm oil biodiesel production using exergy analysis. Comput. Aided Chem. Eng. 2012, 30, 207-211.

27. Talens, L.; Villalba, G.; Gabarrell, X. Exergy analysis applied to biodiesel production. Resour. Conserv. Recycl. 2007, 51, 397-407. [CrossRef]

28. Gholami, A.; Hajinezhad, A.; Pourfayaz, F.; Ahmadi, M.H. The effect of hydrodynamic and ultrasonic cavitation on biodiesel production: An exergy analysis approach. Energy 2018, 160, 478-489. [CrossRef]

29. Talens, L.; Villalba, G.; Sciubba, E.; Gabarrell, X. Extended exergy accounting applied to biodiesel production. Energy 2010, 35, 2861-2869. [CrossRef]

30. Mehrpooya, M.; Ghorbani, B.; Bahnamiri, F.K.; Marefati, M. Solar fuel production by developing an integrated biodiesel production process and solar thermal energy system. Appl. Therm. Eng. 2020, 167, 114701. [CrossRef]

31. Seyyed, M.; Reza, H.; Mosayeb, B.; Abdollahpour, M. Economic evaluation and energy/exergy analysis of PV/Wind/PEMFC energy resources employment based on capacity, type of source and government incentive policies: Case study in Iran. Sustain. Energy Technol. Assess. 2021, 43, 100963. [CrossRef]

32. Khoshgoftar, M.; Onishi, V. Energy, Exergy, and Thermo-Economic Analysis of Renewable Energy-Driven Polygeneration Systems for Sustainable Desalination. Processes 2021, 9, 210. [CrossRef]

33. León, J.A.; Montero, G.; Coronado, M.; Ayala, J.R.; García, C.; Luna, A.; Vázquez, A.M. Solar Energy for a Solvent Recovery Stage in a Biodiesel Production Process. Int. J. Photoenergy 2016, 2016, 1048095. [CrossRef]

34. León, J.A.; Montero, G.; Coronado, M.A.; García, C.; Campbell, H.E.; Ayala, J.R.; Montes, D.; Sagaste, C.A. Renewable Energy Integration: Economic Assessment of Solar Energy to Produce Biodiesel at Supercritical Conditions. Int. J. Photoenergy 2018, 2018, 8769582. [CrossRef]

35. Morais, S.; Mata, T.M.; Martins, A.A.; Pinto, G.A.; Costa, C.A.V. Simulation and life cycle assessment of process design alternatives for biodiesel production from waste vegetable oils. J. Clean. Prod. 2010, 18, 1251-1259. [CrossRef]

36. Moradi-kheibari, N.; Ahmadzadeh, H.; Murry, M.A.; Liang, H.Y.; Hossein, M. Fatty Acid Profiling of Biofuels Produced from Microalgae, Vegetable Oil, and Waste Vegetable Oil. In Advances in Feedstock Conversion Technologies for Alternative Fuels and Bioproducts; Woodhead Publishing: Sawston, UK, 2019; pp. 239-254.

37. Kusdiana, D.; Saka, S. Effects of water on biodiesel fuel production by supercritical methanol treatment. Bioresour. Technol. 2004, 91, 289-295. [CrossRef]

38. Marulanda, V.F. Biodiesel production by supercritical methanol transesterification: Process simulation and potential environmental impact assessment. J. Clean. Prod. 2012, 33, 109-116. [CrossRef]

39. Kuravi, S.; Trahan, J.; Goswami, D.Y.; Rahman, M.M.; Stefanakos, E.K. Thermal energy storage technologies and systems for concentrating solar power plants. Prog. Energy Combust. Sci. 2013, 39, 285-319. [CrossRef]

40. Alayi, R.; Kasaeian, A.; Atabi, F. Thermal Analysis of Parabolic Trough Concentration Photovoltaic/Thermal System for Using in Buildings. Environ. Prog. Sustain. Energy 2019, 38, 13220. [CrossRef]

41. Kalogirou, S.A. Solar thermal collectors and applications. Prog. Energy Combust. Sci. 2004, 30, 231-295. [CrossRef]

42. Kalogirou, S.A. Use of TRNSYS for modeling and simulation of a hybrid pv-thermal solar system for Cyprus. Renew. Energy 2001, 23, 247-260. [CrossRef]

43. Hobbi, A.; Siddiqui, K. Optimal design of a forced circulation solar water heating system for a residential unit in cold climate using TRNSYS. Sol. Energy 2009, 83, 700-714. [CrossRef]

44. Duffie, J.A.; Beckman, W.A. Solar Engineering of Thermal Processes, 4th ed.; Wiley: New York, NY, USA, 2013 ; pp. 653-668.

45. Petela, R. Exergy of Heat Radiation. J. Heat Transf. 1964, 86, 187-192. [CrossRef]

46. Antonova, Z.A.; Krouk, V.S.; Pilyuk, Y.E.; Maksimuk, Y.V.; Karpushenkav, L.S.; Krivov, M.G. Exergy analysis of canola-based biodiesel production in Belarus. Fuel Process. Technol. 2015, 138, 397-403. [CrossRef]

47. Khounani, Z.; Hosseinzadeh, H.; Nazemi, F.; Shaeifi, M.; Karimi, K.; Tabatabaei, M.; Aghbashlo, M.; Lam, S.S. Exergy analysis of a whole-crop safflower biorefinery: A step towards reducing agricultural wastes in a sustainable manner. J. Environ. Manag. 2021, 279, 111822. [CrossRef] [PubMed] 
48. Khoobbakht, G.; Kheiralipour, K.; Rasouli, H.; Rafiee, M.; Hadipour, M.; Karimi, M. Experimental exergy analysis of transesterification in biodiesel production. Energy 2020, 196, 117092. [CrossRef]

49. Jaimes, W.; Acevedo, P.; Kafarov, V. Exergy Analysis of Palm Oil Biodiesel Production. Chem. Eng. Trans. 2010, 21, 1345-1350.

50. Mari, J.; Mari1, M.; Ferreira, M.; Conceição, W.; Andrade, C. Comparative exergetic analysis of two biodiesel production routes. DEStech Trans. Eng. Technol. Res. 2017, 1-5. [CrossRef] 